\title{
The Effect of Administration of Immunoglobulin to Newborn Rats with Escherichia coli Sepsis and Meningitis
}

\author{
THOMAS E. HARPER, ROBERT D. CHRISTENSEN, AND GERALD ROTHSTEIN \\ Divisions of Human Development and Aging, and Hematology, University of Utah School of Medicine, \\ Salt Lake City, Utah 84132
}

\begin{abstract}
Newborn rats 24-36 h old were injected transthoracically with various doses of Escherichia coli $\mathrm{K} 1$. Eighty-six of 92 rats which received $10^{4}$ colony-forming units/g body weight were dead within $48 \mathrm{~h}$. Two $\mathrm{h}$ after injection, $E$. coli were recovered from the blood of six of six rats and from the cerebrospinal fluid of two of six. Sixteen h after injection, $E$. coli were recovered from all blood (7/7) and spinal fluid (11/11) specimens cultured. Animals inoculated with $10^{4} \mathrm{E}$. coli/g exhibited neutropenia and depletion of the neutrophil storage pool. In other studies, newborn rats inoculated with $E$. coli were injected intraperitoneally with various doses of human serum immunoglobulin, modified for intravenous use (MISG). One hundred percent $(25 / 25)$ injected with $1500 \mathrm{mg} / \mathrm{kg}$ lived. In contrast to infected animals injected with albumin (controls), MISG recipients did not develop neutropenia nor did they deplete their neutrophil reserves. The effects of treating infected animals with MISG, antibiotics, or a combination of antibiotics plus MISG were compared. When administered within $2 \mathrm{~h}$ after the $E$. coli, all treatments resulted in survival rates of over $75 \%$. However, when delayed for $6 \mathrm{~h}, 63 \%(17 / 27)$ of antibiotic recipients, $50 \%(12 / 24)$ of MISG recipients, and $91 \%(30 / 33)$ of those receiving both treatments lived $(p<0.01$ versus antibiotics or MISG). (Pediatr Res 22: 455-460, 1987)
\end{abstract}

\section{Abbreviations}

GBS, group B streptococcus

MISG, human immune serum globulin, modified for intravenous use

PBS, phosphate-buffered saline

KRP, Krebs-Ringer phosphate solution

CSF, cerebrospinal fluid

CFU, colony-forming units

The distinctive susceptibility of neonates to bacterial infection has been observed in many species, including rats (1). Using newborn rats as a model of neonatal GBS sepsis, investigators have observed that neutropenia and depletion of the marrow neutrophil reserves precede septic death $(2,3)$. These neutrophil abnormalities have also been observed in human neonates with GBS sepsis $(4,5)$. In contrast to the poor outcome observed in

Received December 2, 1986; accepted May 18, 1987

Correspondence Dr. Robert D. Christensen, Division of Human Development and Aging, University of Utah School of Medicine, 50 North Medical Drive, Salt Lake City, UT 84132.

Supported by Grants HD-18069 and AM-07115 from the National Institutes of Health. septic, neutrophil-depleted patients, the prognosis is better for those who do not develop neutropenia and who sustain only a moderate reduction in the marrow neutrophil reserve (6).

Although GBS accounts for most instances of neonatal sepsis in the United States, Escherichia coli is responsible for $30-40 \%$ of cases (7), and for approximately $30-40 \%$ of cases of neonatal bacterial meningitis (8). We previously observed neutropenia and depletion of the marrow neutrophil reserve in four human neonates with $E$. coli infection (2). However, it is not known whether $E$. coli regularly produces these abnormalities in the manner described during neonatal GBS infection (5). The suckling rat has been used as a model of $E$. coli sepsis and meningitis by several investigators $(10,11)$, who have demonstrated the severity of infection to be related to the larger doses of organisms, the younger aged animals, and the presence of the $\mathrm{K} 1$ antigen. In experimental neonatal infection with GBS, specific antibacterial antibody has been shown to improve the outcome (12-16) and to prevent the development of neutropenia and depletion of the neutrophil reserves (13). Recent studies have demonstrated similar beneficial effects on outcome in suckling rat models of $E$. coli infection, whether the antibody is administered naturally through the colostrum of immunized dams (17) or orally as hyperimmune horse serum (17) or intraperitoneally as specific monoclonal IgM antibody (18) or MISG containing opsonic antibody (19). However, no studies have examined the effect of antibody to $E$. coli on neutrophil kinetics.

In order to further study the effects of antibody in $E$. coli infection, we developed a model for $E$. coli sepsis and meningitis, inoculating newborn rats with a strain of $E$. coli expressing the $\mathrm{K} 1$ antigen. In these studies we (1) quantified circulating and storage neutrophil populations serially, (2) compared the neutrophil kinetics of infected rats treated with MISG to the neutrophil response of others treated with albumin as a control, and (3) compared the survival of infected rats treated with MISG, antibiotics, and a combination of MISG plus antibiotics.

\section{METHODS}

Organism. E. coli, identified as 085w:K1:NM ( $E$. coli Reference Center, Philadelphia, PA), were stored at $-70^{\circ} \mathrm{C}$ until use. Then aliquots were thawed and allowed to grow overnight in fresh Todd-Hewitt or tryptic-soy broth. Organisms were sedimented by centrifugation and washed three times in PBS or KRP. The concentration of bacteria was standardized by its optical density at $600 \mathrm{~nm}$, and suspensions of $0.9-2.9 \times 10^{9}, 10^{8}$, $10^{7}$, or $10^{6}$ organisms $/ \mathrm{ml}$ were prepared. Concentrations were confirmed by colony counts on McConkey or tryptic-soy agar. The $E$. coli were sensitive to both ampicillin and gentamicin (Autobac, General Diagnostics, Morristown, NJ).

Animals. Pregnant Sprague-Dawley albino rats, obtained from Simonsen Laboratories (Gilroy, CA), were housed in the Uni- 
versity of Utah Vivarium until litters delivered. When the pups were 24-36 h old, litters were mixed; and, using a microliter syringe (Hamilton Co., Reno, NV), $6.5 \mu \mathrm{l}$ of $E$. coli suspension/ $\mathrm{g}$ body wt was injected into the right lateral thorax after the skin was washed with $70 \%$ ethyl alcohol.

Cultures. Blood was obtained sterilely from the jugular vein, after washing the area with $70 \%$ ethyl alcohol, or from the inferior vena cava. CSF was obtained by exposing the dura over the cisterna magna by dissection and sterilely penetrating the dura with a needle or scalpel blade. Twenty-five $\mu$ l of CSF was collected in a micropipet. All blood-tinged specimens were discarded. To assess the degree of blood contamination, erythrocyte counts were performed on specimens from 10 uninfected animals. Specimens were incubated overnight in Todd-Hewitt or tryptic-soy broth and subcultured in $100 \mu \mathrm{l}$ aliquots on ToddHewitt or tryptic-soy agar plates. Colonies were identified as $E$. coli by morphology.

Quantitative cultures for $E$. coli were performed using $50 \mu \mathrm{l}$ of jugular venous blood or $25 \mu \mathrm{l}$ of CSF. Specimens were plated directly or in various dilutions of sterile water in a volume of $100 \mu 1$ on tryptic-soy plates and spread with a glass rod. After overnight growth, colonies were counted with the aid of a touchsensitive automatic colony counter (Quebec Colony Counter, American Optical Corp., Buffalo, NY).

MISG. MISG (Gamimune-N, lot \#PR 2964, Cutter Biological, Berkeley, $\mathrm{CA}$ ) was prepared at an acid $\mathrm{pH}(4.25)$ as a $5 \%$ solution in $10 \%$ maltose. It was administered intraperitoneally to groups of 17-25 newborn rats in doses of $125,250,500,1000,1500$, and $2000 \mathrm{mg} / \mathrm{kg}$ (corresponding to $5,10,15,20,30$, and $40 \mathrm{ml} /$ $\mathrm{kg}$ ). Other animals (controls) were given $0.1 \%$ albumin in $10 \%$ maltose, administered in the same volume as the MISG.

In other studies, groups of 24-48 newborn rats inoculated with $10^{4} \mathrm{E} . \mathrm{coli} / \mathrm{g}$ were given one of three forms of therapy: 1) MISG (1500 $\mathrm{mg} / \mathrm{kg}$ intraperitoneally), 2) antibiotics (ampicillin, 200$300 \mathrm{mg} / \mathrm{kg} /$ day, and gentamicin, $5-7 \mathrm{mg} / \mathrm{kg} /$ day, intramuscularly twice daily for 2 days), or 3) MISG and antibiotics. Other animals (controls) were given injections of sterile normal saline, rather than antibiotics, and albumin in $10 \%$ maltose, rather than MISG. The treatments were administered at the same time as and at various intervals after the $E$. coli: $2,6,16$, or $22 \mathrm{~h}$.

Neutrophil kinetics. Two, 6 , and $22 \mathrm{~h}$ after the simultaneous administration of $E$. coli and either MISG or albumin, venous blood was obtained from groups of five to nine rats and counted electronically (Coulter Electronics, Hialeah, FL). Cover slip smears were prepared for a 100-cell differential count. The number of neutrophils within the storage pool was determined by methods we have previously described $(2,13)$, in which the components of the reserve within the skeletal marrow, liver, and spleen were determined by electronic and differential counts of cells from these organs.

Radiolabeled MISG. MISG was radioiodinated by employing ${ }^{125}$ I and 1,3,4,6-tetrachloro-3 $\alpha, 6 \alpha$-diphenylglycoluril (Iodogen) (Pierce Chemical Co., Rockford, IL) (20). Iodogen was dissolved in chloroform to a concentration of $416 \mu \mathrm{g} / \mathrm{ml}$ and $60 \mu \mathrm{l}$ were placed in a pyrex tube $(10 \times 75 \mathrm{~mm})$. The tube was rapidly vacuum-dried and placed on ice. Thirty $\mu$ l of $0.2 \mathrm{M}$ sodium phosphate dibasic buffer or PBS plus $10 \mu \mathrm{l}$ of MISG were added, followed by $10 \mu \mathrm{l}(1 \mathrm{mCi})$ of carrier-free $\mathrm{Na}^{125} \mathrm{I}^{-}$in $0.1 \mathrm{~N} \mathrm{NaOH}$ (Amersham Corp., Arlington Heights, IL), resulting in a total reaction volume of $50 \mu \mathrm{l}$. The mixture was kept on ice for 20 min with gentle agitation. Bound ${ }^{125} I$ was collected by passage over a G-10 Sephadex column and concentrated by membrane cone ultrafiltration (Type CF25, Amicon Corp., Danvers, MA). The protein content was determined by the Lowry method (21). Radiolabeled MISG was then diluted with unlabeled MISG to give $3.0-3.2 \times 10^{7} \mathrm{cpm} / \mathrm{ml}$ or $7.4-7.6 \times 10^{5} \mathrm{cpm} / \mu \mathrm{g}$ protein. The final diluted produce was administered to neonatal rats intraperitoneally in a volume of $225-250 \mu l(1500 \mathrm{mg} / \mathrm{kg}$ of MISG).

Eleven newborn rats were inoculated with $10^{4} \mathrm{E}$. coli/g and at the same time or $6 \mathrm{~h}$ later, injected intraperitoneally with radiolabeled MISG. Three control animals were given KRP instead of $E$. coli, followed by radiolabeled MISG. Twenty-two h after the MISG administration, blood and CSF were obtained and counted on an automated gamma counter (Gamma 8000, Beckman Instruments, Inc., Fullerton, CA). The concentrations of radiolabeled MISG, expressed in $\mathrm{mg} / 100 \mathrm{ml}$, in blood and CSF were then calculated.

Statistics. Differences in neutrophil kinetic studies were analyzed using the Student's $t$ test. Survival was analyzed using the Fisher exact test.

\section{RESULTS}

In mortality studies, $21 \%$ of newborn rats inoculated with $10^{3}$ E. coli CFU/g body weight were dead within 7 days (Fig. 1). However, $93 \%$ which received $10^{4} / \mathrm{g}$ were dead by $48 \mathrm{~h}$, and $99 \%$ had died by 6 days. All animals which received larger inocula of $10^{5} / \mathrm{g}$ or $10^{6} / \mathrm{g}$ were dead within $40 \mathrm{~h}$ of injection. Since $10^{4} \mathrm{CFU} / \mathrm{g}$ resulted in greater than $90 \%$, but less than $100 \%$ mortality, this inoculum was selected for all subsequent experiments.

The results of blood and CSF cultures following inoculation with $10^{4} \mathrm{E}$. coli $\mathrm{CFU} / \mathrm{g}$ are displayed in Figure 2. E. coli were

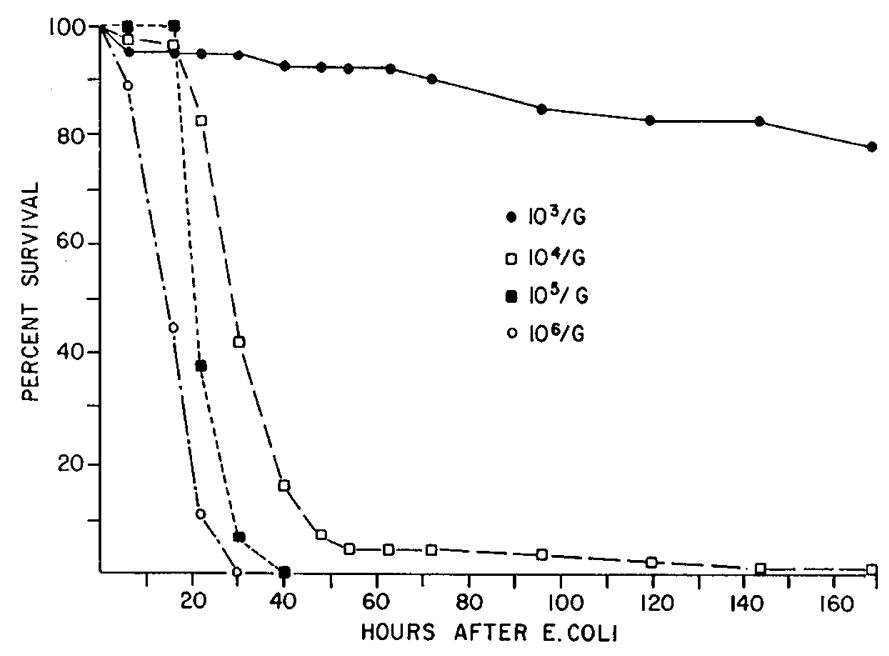

Fig. 1. Survival of groups of 16-92 newborn rats following transthoracic inoculation with four different doses of $E$. coli $\mathrm{K} 1$.

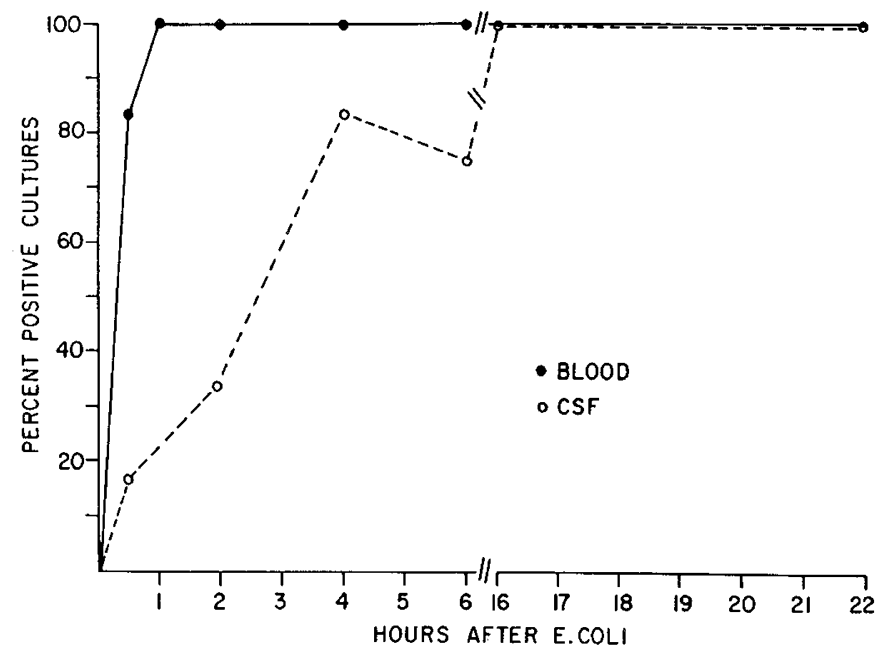

Fig. 2. Cultures of the blood $(n=32)$ and CSF $(n=68)$ in groups of newborn rats following transthoracic inoculation of $10^{4}$ E. coli $\mathrm{K1} / \mathrm{g}$ body weight. 
recovered from the blood of five of six animals $1 / 2$ after the inoculation and from all blood cultures $(26 / 26)$ at each time thereafter. $E$. coli were recovered from the CSF of one of six rats $1 / 2$ after the bacterial inoculation, from two of six after $2 \mathrm{~h}$, from five of six after $4 \mathrm{~h}$, from 24 of $32(75 \%)$ after $6 \mathrm{~h}$, and from 18 of $18(100 \%)$ thereafter.

Quantitative blood and CSF cultures were also performed at various times following the inoculation. Sixteen $\mathrm{h}$ after injection, blood cultures were obtained on 12 animals and found to contain $1.4 \pm 1.4$ (mean $\pm \mathrm{SD}) \times 10^{6} \mathrm{E}$. coli $/ \mathrm{ml}$. Seven CSF samples obtained at this time contained $6.6 \pm 3.1 \times 10^{2} \mathrm{E}$. coli $/ \mathrm{ml}$. Within $22 \mathrm{~h}$ blood cultures $(n=10)$ contained $9.8 \pm 14.8 \times 10^{6}$ $E$. coli $/ \mathrm{ml}$ and CSF specimens $(n=2) 1.1 \pm 1.1 \times 10^{5} / \mathrm{ml}$. The red blood cell concentration in the CSF was $459 \pm 371$ cells/ $\mathrm{mm}^{3}$ (mean $\pm \mathrm{SD}$ ). Because the red blood cell concentration in peripheral blood of newborn rats is about $2 \times 10^{6} / \mathrm{mm}^{3}(22)$, at most the CSF specimens were contaminated by one part blood for every 4000 parts CSF. Therefore, contamination of CSF by blood containing $<2.5 \times 10^{6} \mathrm{E}$. coli $\mathrm{CFU} / \mathrm{ml}$ could not explain the quantity of organisms recovered from the CSF of these animals. These data support the diagnosis of meningitis.

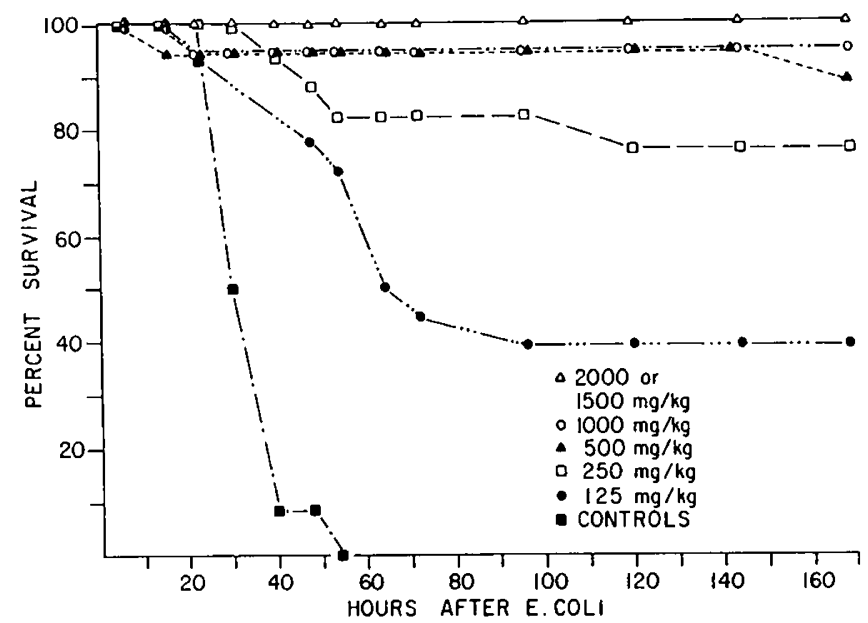

Fig. 3. Survival of groups of $17-25$ newborn rats after a transthoracic inoculation of $10^{4} \mathrm{E}$. coli $\mathrm{K} 1 / \mathrm{g}$ body weight, followed immediately thereafter by the intraperitoneal administration of various doses of MISG.

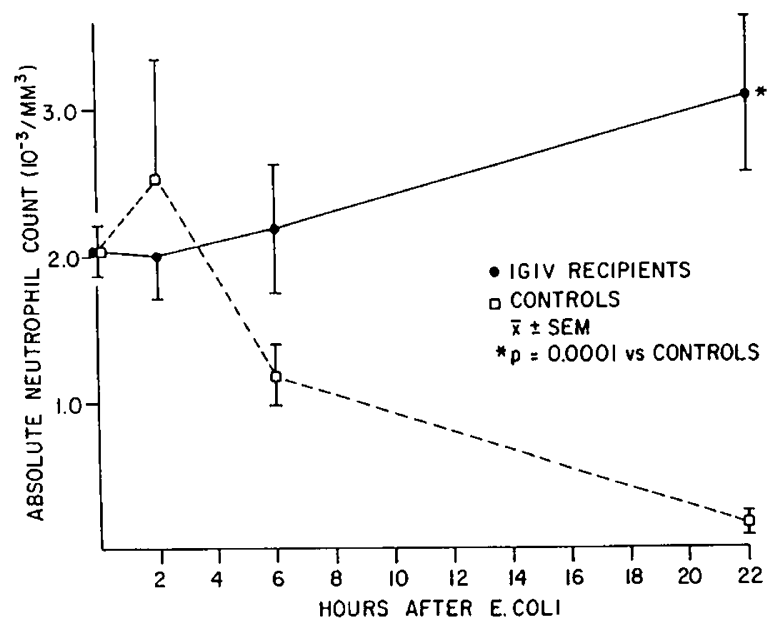

Fig. 4. The blood neutrophil count in groups of newborn rats 2, 6, and $22 \mathrm{~h}$ following inoculation with $10^{4} \mathrm{E}$. coli body weight. Five to six infected animals received an intraperitoneal injection of $1500 \mathrm{mg} / \mathrm{kg}$ of MISG, and their neutrophil counts are shown by solid circles. Eight to nine infected animals received an intraperitoneal injection of the same volume of albumin (control), and their neutrophil counts are shown by open squares.
The survival of groups on newborn rats, transthoracically injected with $10^{4} \mathrm{E}$. coli $/ \mathrm{g}$ followed immediately by an intraperitoneal injection of various doses of MISG, is shown in Figure 3. No deaths occurred among 25 infected animals receiving 1500 $\mathrm{mg} / \mathrm{kg}$ and in only one of 18 animals which received $1000 \mathrm{mg} /$ $\mathrm{kg}$ MISG. When less MISG was administered, survival diminished (Fig. 3). In all subsequent experiments $1500 \mathrm{mg} / \mathrm{kg}$ of MISG was given.

The blood neutrophil concentration in groups of five to nine newborn rats following inoculation of $10^{4} \mathrm{E}$. coli/g is shown in Figure 4. One group of infected rats received an intraperitoneal injection of MISG, $1500 \mathrm{mg} / \mathrm{kg}$, while the other group received albumin. Six $h$ after the bacterial inoculation, blood neutrophils had diminished to $1.19 \pm 0.21$ (mean $\pm \mathrm{SEM}) \times 10^{3} / \mathrm{mm}^{3}$ in the albumin recipients but remained normal $\left(2.18 \pm 0.43 \times 10^{3} /\right.$ $\left.\mathrm{mm}^{3}\right)$ in those which received MISG $(p=0.06)$. By $22 \mathrm{~h}$ after inoculation, the infected animals which had received MISG had increased concentration of blood neutrophils $\left(3.08 \pm 0.53 \times 10^{3} /\right.$ $\mathrm{mm}^{3}$ ), while infected animals which received albumin exhibited marked neutropenia $\left(0.16 \pm 0.08 \times 10^{3} / \mathrm{mm}^{3}, p<0.001\right)$.

The ratio of immature neutrophils (band neutrophils + metamyelocytes) to total neutrophils (segmented neutrophils + band neutrophils + metamyelocytes) in the blood of infected animals is shown in Figure 5. Two $h$ after the bacterial inoculation, animals which had received MISG displayed a more elevated ratio $(0.71 \pm 0.05$, mean $\pm S E M)$ than did albumin recipients $(0.48 \pm 0.07, p<0.03)$. However, by $22 \mathrm{~h}$ the ratio was greater in animals treated with albumin $(0.86 \pm 0.08)$ than in those which received MISG $(0.47 \pm 0.05, p<0.005)$.

The neutrophil storage pool (the total of all segmented neutrophils, band neutrophils, and metamyelocytes within the skeletal marrow, liver, and spleen) in groups of five to nine newborn rats 2,6 , and $22 \mathrm{~h}$ after inoculation of $10^{4} \mathrm{E}$. coli/g body weight is shown in Figure 6. MISG promoted early mobilization of neutrophils from the marrow. Two $h$ after inoculation, neutrophil reserves were more reduced in the MISG recipients [containing $4.44 \pm 0.64$ (mean $\pm \mathrm{SEM}) \times 10^{6}$ cells/animal] than in the controls, which received albumin $(7.93 \pm 0.86 \times 10 / 6$ cells, $p<$ $0.01)$. Later, MISG prevented exhaustion of the neutrophil reserves. After $22 \mathrm{~h}$ control animals displayed exhaustion of their neutrophil supply (containing only $1.38 \pm 0.30 \times 10^{6}$ cells)

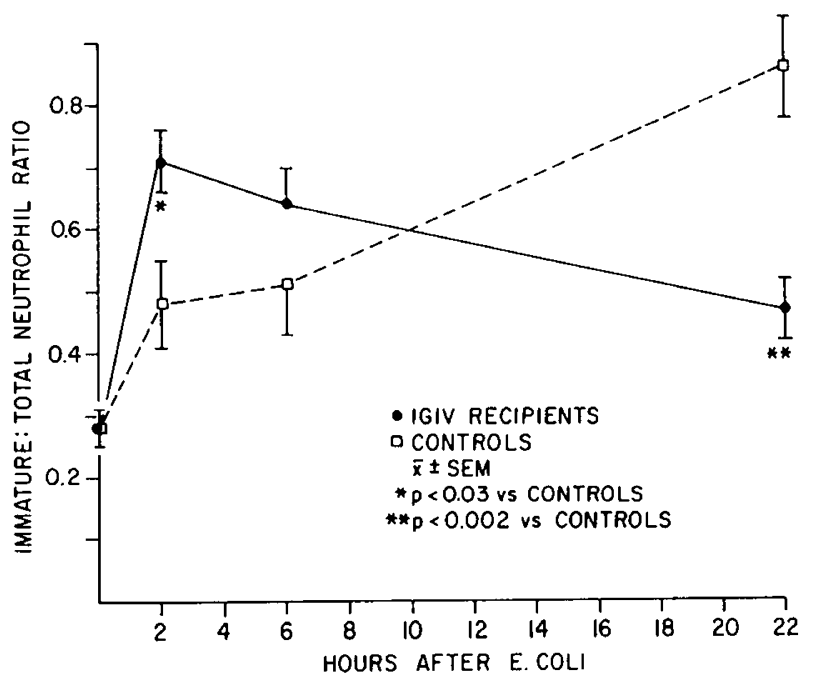

Fig. 5. The ratio of immature neutrophils (band neutrophils + metamyelocytes) to total neutrophils (segmented neutrophils + band neutrophils + metamyelocytes) in groups of newborn rats 2,6 , and $22 \mathrm{~h}$ following inoculation with $10^{4} \mathrm{E}$. coli/g. Five to six infected animals received an intraperitoneal injection of $1500 \mathrm{mg} / \mathrm{kg}$ of MISG and their immature/total blood neutrophil ratios are shown by solid circles. Eight to nine infected animals received an intraperitoneal injection of the same volume of albumin (control), and their ratios are shown by open squares. 


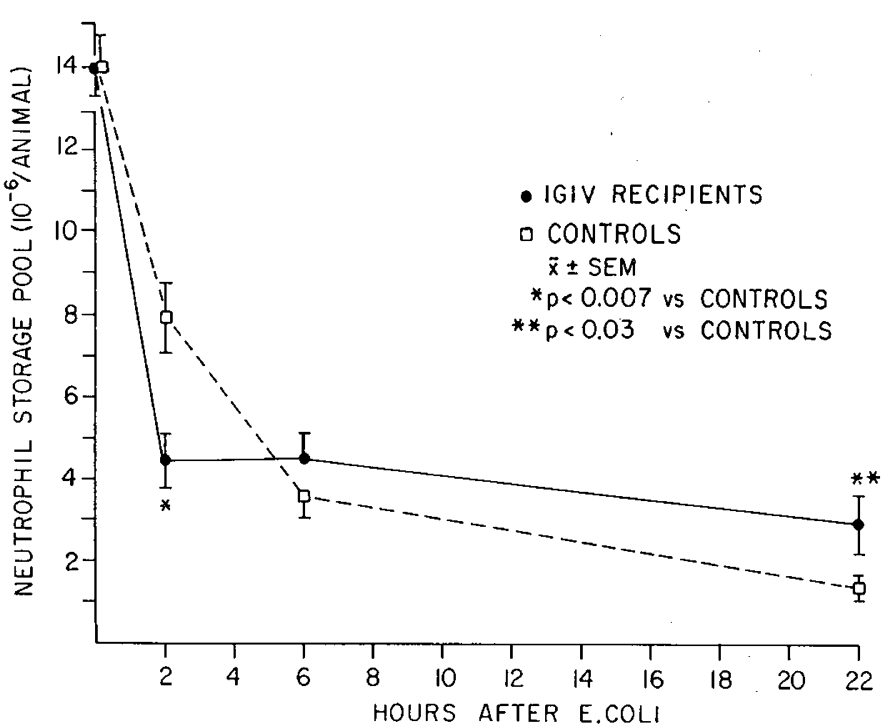

Fig. 6. The neutrophil storage pool (all segmented neutrophils + band neutrophils + metamyelocytes within the skeletal marrow + liver + spleen) in groups of newborn rats 2,6 , and $22 \mathrm{~h}$ following inoculation with $10^{4} \mathrm{E}$. coli/g body weight. Five to six infected animals received an intraperitoneal injection of $1500 \mathrm{mg} / \mathrm{kg}$ of MISG, and their neutrophil storage pool values are shown by solid circles. Eight to nine infected animals received an intraperitoneal injection of the same volume of albumin (control), and their neutrophil reserves are shown by open squares.

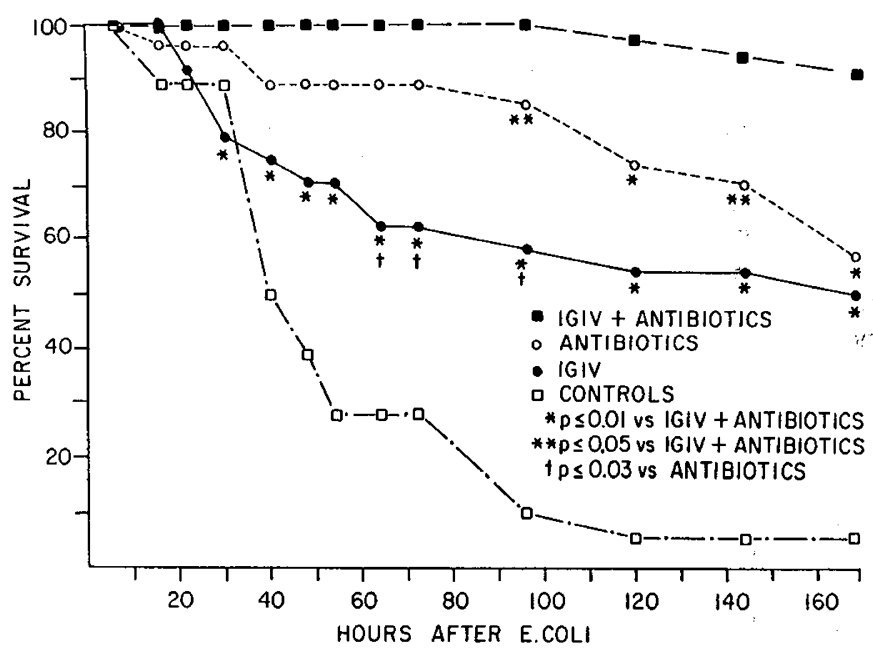

Fig. 7. The survival of groups of 24-33 newborn rats inoculated with $10^{4} \mathrm{E} . \mathrm{coli} / \mathrm{g}$ body weight and after $6 \mathrm{~h}$ treated with one of three therapies. Survival of infected rats treated with MISG $(1500 \mathrm{mg} / \mathrm{kg})$ is shown by solid circles. Survival of those treated with antibiotics is shown by open circles and of those treated with MISG and antibiotics by solid squares. Infected animals treated with albumin (intraperitoneal) and saline (intramuscular) injections are shown by open squares.

whereas MISG recipients had a larger population of stored neutrophils $\left(3.30 \pm 0.70 \times 10^{6}\right.$ cells, $\left.p<0.05\right)$. Thus, newborn rats infected with $E$. coli and treated with MISG released neutrophils from their reserves more promptly than did controls. In addition, MISG recipients did not completely exhaust their neutrophil reserves as did controls.

Other groups of animals were inoculated with $E$. coli and following $2 \mathrm{~h}$ treated with either MISG, antibiotics, or a combination of the two. Substantial survival was observed in all groups: $75 \%(18 / 24)$ with MISG, $86 \%(24 / 28)$ with antibiotics, and $79 \%$ $(38 / 48)$ with the combination. However, when treatments were

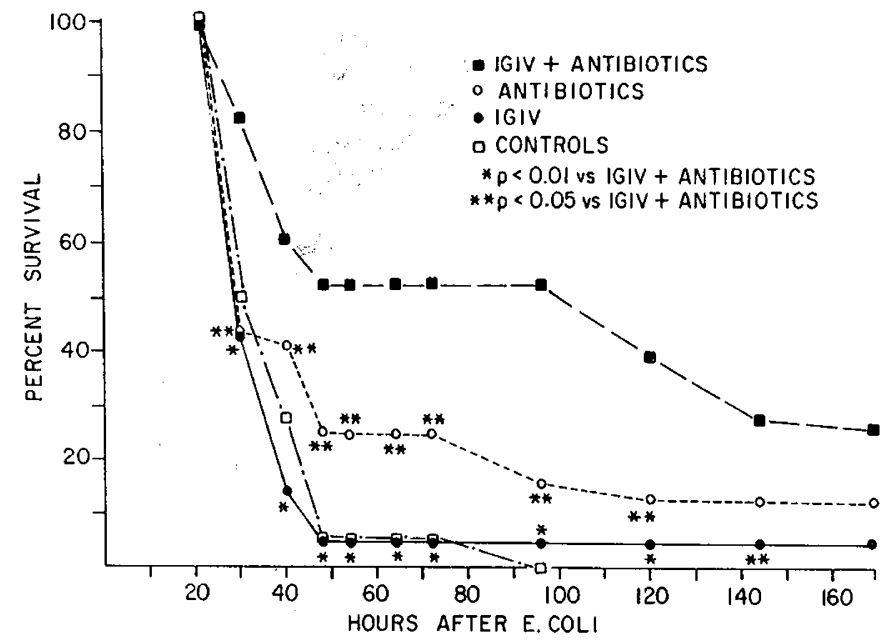

Fig. 8. Survival of groups of 25-43 newborn rats inoculated with $10^{4}$ E. coli/g body weight who were alive after $22 \mathrm{~h}$ and treated with one of three therapies. Survival of infected rats treated with MISG $(1500 \mathrm{mg} /$ $\mathrm{kg}$ ) is shown by solid circles. Survival of those treated with antibiotics is shown by open circles and of those treated with MISG and antibiotics by solid squares. Infected animals treated with albumin (intraperitoneal) and saline (intramuscular) injections are shown by open squares.

Table 1. Accumulation of administered $\operatorname{IgG}$ in blood and CSF*

\begin{tabular}{cccc}
\hline $\begin{array}{c}\text { E. coli } \\
\text { inoculation }\end{array}$ & $n$ & $\begin{array}{c}\text { Blood } \\
\text { concentration } \\
(\mathrm{mg} / 100 \mathrm{ml})\end{array}$ & $\begin{array}{c}\text { CSF } \\
\text { concentration } \\
(\mathrm{mg} / 100 \mathrm{ml})\end{array}$ \\
\hline Yes & 11 & $372 \pm 59$ & $24 \pm 5$ \\
& & $\mathrm{NS}$ & $\mathrm{NS}$ \\
No & 3 & $309 \pm 25$ & $26 \pm 2$ \\
\hline
\end{tabular}

* All animals received $1500 \mathrm{mg} / \mathrm{kg}{ }^{125} \mathrm{I}-\mathrm{MISG}$ intraperitoneally. Assays were performed on blood and CSF obtained 16 or $22 \mathrm{~h}$ after MISG administration to rats inoculated with either $10^{4} \mathrm{E}$. coli/g or KRP (mean $\pm \mathrm{SD}$ ).

delayed until $6 \mathrm{~h}$ after the bacterial inoculation (when neutrophil stores had already been significantly reduced), MISG plus antibiotics was significantly better than either MISG or antibiotics alone $(p<0.01$, Fig. 7). Even when delayed until $22 \mathrm{~h}$ after the $E$. coli inoculation, the therapeutic advantage of the combined treatment persisted (Fig. 8).

Eleven animals with meningitis and three control animals received radiolabeled MISG intraperitoneally (Table 1). After 22 $\mathrm{h}$ the blood and CSF levels of IgG were similar in the two groups, reaching blood concentrations of labeled IgG of more than 300 $\mathrm{mg} / 100 \mathrm{ml}$. These increments probably represent a substantial increase in blood $\mathrm{IgG}$ levels since newborn rats have a blood level of $\operatorname{IgG}_{2 \mathrm{a}}$ (the primary rat $\mathrm{IgG}$ ) of only $100 \mathrm{mg} / 100 \mathrm{ml}$ in contrast to the adult level of $691 \mathrm{mg} / 100 \mathrm{ml}(21)$.

\section{DISCUSSION}

Specific antibacterial antibody has an important role in neonatal defense against bacterial infection (24). In clinical studies of neonatal GBS disease, a lack of opsonic antibody toward GBS correlates with a poor outcome (25). Furthermore, in experimental models of neonatal GBS sepsis, infected animals treated with anti-GBS antibody exhibit markedly improved survival (26-28). Preparations of MISG have been successfully used as a source of anti-GBS antibody, improving the outcome of infected neonatal rats $(13,15,16)$. Many in vitro studies have also demonstrated the requirement of antibody for effective resistance to encapsulated $E$. coli (29-31). Furthermore, animal studies have shown effectiveness of treating $E$. coli infections with antibody directed against specific $E$. coli antigens, especially the K1 polysaccharide 
$(17,18,32-34)$. In humans, however, the $\mathrm{K} 1$ antigen is only weakly immunogenic (34-36) and in fact elicits predominantly an IgM antibody response (37). Preparations of MISG, therefore, often have very low anticapsular- $E$. coli titers (37). Cross et al. (34) did not demonstrate any opsonic antibody against $E$. coli $\mathrm{K} 1$ in five preparations of MISG. However, Hill and Bathras (38) detected modest opsonic antibody in six different lots of the preparation used in the present study. Bortolussi and Fischer (19) has also recently reported the use of MISG as a source of opsonic antibody which conferred improved survival on newborn rats infected with $E$. coli $\mathrm{K} 1$. Nonetheless, specific or crossreactive antibody to the $\mathrm{O}$-antigen may also play a role in humoral defense against $E$. coli $\mathrm{K} 1$ (39).

The beneficial effect of antibody appears, at least in part, to be mediated through its effect on the neutrophil response to bacterial infection. Neutropenia and depletion of the neutrophil reserves have been well documented in fatal neonatal GBS infection (2-6), and antibody has been shown to cause a marked diminution in this adverse response. However, little information has been available previously on either neutrophil kinetics during gram-negative infection in neonates or on the effect of antibody on the neutrophil response.

In the present studies we determined that $E$. coli $\mathrm{K} 1$, administered transthoracically into rats $24-36 \mathrm{~h}$ old, resulted in mortality in a dose-dependent fashion. Animals inoculated with $10^{4}$ CFU/g body weight developed neutropenia, depletion of neutrophil reserves, and death within $48 \mathrm{~h}$. However, neutropenia and exhaustion of neutrophil reserves did not occur in animals which, immediately after the bacterial inoculation, received an intraperitoneal injection of MISG, $1500 \mathrm{mg} / \mathrm{kg}$. Moreover, the increase in immature neutrophil forms in the peripheral blood of treated animals $2 \mathrm{~h}$ after $E$. coli inoculation along with the simultaneous decrease in storage neutrophils suggests a more rapid mobilization of neutrophils into the blood. MISG as a treatment for newborn rats with $E$. coli infection was also compared with antibiotics and with the combination of antibiotics plus MISG. If administered within $2 \mathrm{~h}$ following the bacterial inoculation, all treatments were equally effective in preventing mortality. However, if delayed for $6 \mathrm{~h}$, a time at which $75 \%$ of animals had meningitis and all had diminished neutrophil reserves, the combined treatment was clearly superior. When delayed for $22 \mathrm{~h}$, a time at which all animals had meningitis, neutropenia, and severe depletion of neutrophil reserves, none of the treatments was very effective. However, even under these circumstances, the combination of MISG and antibiotics resulted in significantly greater survival than did either treatment alone.

Givner et al. (40) demonstrated that MISG alone does not kill bacteria in vitro but rather acts as an opsonin. Similarly, we (13) reported that a major effect of MISG administration to infected neonatal rats was an improved efficiency in migration of neutrophils to inflammatory sites. Therefore, the fact that in the present studies MISG improved survival of infected rats when administration was delayed until after marked neutropenia and neutrophil storage pool depletion had occurred appears incongruous with its expected mechanism of action. These observations might be explained by the hypotheses that in neutropenic subjects MISG improves the efficiency of bacterial killing by nonneutrophilic phagocytes (41), enhances the function of the reticuloendothelial system (42), supplies noncellular mechanisms such as plasma factors (43), or improves the function of the relatively few remaining neutrophils (44).

Admittedly the present studies cannot distinguish whether the effects of MISG on neutrophil kinetics and survival were the result of specific anti- $E$. coli antibody or some other mechanism. However, the cooperative effect of MISG and antibiotics in improving survival of animals with sepsis and meningitis is striking.

Acknowledgments. The authors thank Jhansirani Reddi, Nancy Taylor, and Nancy Hogan Augustine for technical assist- ance and Jerry Kaplan, Ph.D., for assistance in radioactively labeling MISG.

\section{REFERENCES}

1. Bortolussi R, Ferrieri P, Bjorksten B, Quie PG 1979 Capsular K1 polysaccharide of Escherichia coli: relationship to virulence in newborn rats and resistance to phagocytosis. Infect Immun 25:293-298

2. Christensen RD, Macfarlane JL, Taylor NL, Hill HR, Rothstein G 1982 Blood and marrow neutrophils during experimental group $B$ streptococcal infection: quantification of the stem cell, proliferative, storage, and circulating pools. Pediatr Res 16:549-553

3. Zeligs BJ, Armstrong CD, Walser JB, Bellanti JA 1982 Age-dependent susceptibility of neonatal rats to group B streptococcal type III infection: correlation of severity of infection and response of myeloid pools. Infect Immun 37:255263

4. Christensen RD, Rothstein G 1980 Exhaustion of mature marrow neutrophils in neonates with sepsis. J Pediatr 96:316-318

5. Wheeler JG, Chauvenet AR, Johnson CA, Dillard R, Block SM, Boyle R, Abramson JS 1984 Neutrophil storage pool depletion in septic, neutropenic neonates. Pediatr Infect Dis 3:404-409

6. Christensen RD, Bradley PP, Rothstein G 1981 The leukocyte left shift in clinical and experimental neonatal sepsis. J Pediatr 98:101-105

7. Freedman RM, Ingram DL, Gross I, Ehrenkranz RA, Warshaw JB, Baltimore RS 1981 A half century of neonatal sepsis at Yale: 1928-1978. Am J Dis Child 135:140-144

8. Glode MP, Sutton A, Robbins JB, McCracken GH, Gotschlich EC, Kaijser B, Hanson LA 1977 Neonatal meningitis due to Escherichia coli K. I. J Infect Dis 136:S93-97

9. Christensen RD, Rothstein G. Anstall HB, Bybee B 1982 Granulocyte transfusions in neonates with bacterial infection, neutropenia, and depletion of mature marrow neutrophils. Pediatrics 70:1-6

10. Bortolussi R, Ferrieri P, Wannamaker LW 1978 Dynamics of Escherichia coli infection and meningitis in infant rats. Infect Immun 22:480-485

11. Glode MP, Sutton A, Moxon ER, Robbins JB 1977 Pathogenesis of neonatal Escherichia coli meningitis: induction of bacteremia and meningitis in infant rats fed $E$. coli $\mathrm{K} 1$. Infect Immun 16:75-80

12. Christensen KK, Christensen P 1986 Intravenous gamma-globulin in the treatment of neonatal sepsis with special reference to group B streptococci and pharmacokinetics. Pediatr Infect Dis 5:S189-192

13. Harper TE, Christensen RD, Rothstein G, Hill HR 1986 Effect of intravenous immunoglobulin $G$ on neutrophil kinetics during experimental group $B$ streptococcal infection in neonatal rats. Rev Infect Dis 8:S401-408

14. Hill HR, Shigeoka AO, Pincus S, Christensen RD 1986 Intravenous IgG in combination with other modalities in the treatment of neonatal infection. Pediatr Infect Dis 5:S180-184

15. Santos JI, Shigeoka AO, Rote NS, Hill HR 1981 Protective efficacy of a modified immune serum globulin in experimental group B streptococcal infection. J Pediatr 99:873-879

16. Fischer GW, Hunter KW, Wilson SR 1982 Modified human immune serum globulin for intravenous administration: in vitro opsonic activity and in vivo protection against group B streptococcal disease in suckling rats. Acta Paediatr Scand 71:639-644

17. Bortolussi R, Ferrieri P 1980 Protection against Escherichia coli K1 infection in newborn rats by antibody to $\mathrm{K} /$ capsular polysaccharide antigen. Infect Immun 28:111-117

18. Kim KS, Cross AS, Zollinger W, Sadoff J 1985 Prevention and therapy of experimental Escherichia coli infection with monoclonal antibody. Infect Immun 50:734-737

19. Bortolussi R, Fischer GW 1986 Opsonic and protective activity of immunoglobulin, modified immunoglobulin, and serum against neonatal Escherichia coli $\mathrm{K} 1$ infection. Pediatr Res 20:175-178

20. Markwell MAK, Fox CF 1978 Surface-specific iodination of membrane proteins of viruses and eucaryotic cells using 1,3,4,6-tetrachloro-3 $\alpha, 6 \alpha$-diphenylglycoluril. Biochemistry 17:4807-4817

21. Lowry OH, Rosebrough NJ, Farr AL, Randall RJ 1951 Protein measurement with the folin phenol reagent. J Biol Chem 193:265-275

22. Wintrobe MM, Shumacker HB 1936 Erythrocyte studies in the mammalian fetus and newborn: erythrocyte counts, hemoglobin and volume of packed red corpuscles, mean corpuscular volume, diameter and hemoglobin content, and proportion of immature red cells in the blood of fetuses and newborn of the pig, rabbit, rat, cat, dog and man. Am J Anat 58:313-328

23. McGhee JR, Michalek SM, Ghanta VK 1975 Rat immunoglobulins in serum and secretions: purification of rat IgM, IgA and IgG and their quantitation in serum, colostrum, milk and saliva. Immunochemistry 12:817-823

24. Christensen KK, Christensen P, Dahlander K, Faxelius G, Jacobson B, Svenningsen N 1980 Quantitation of serum antibodies to surface antigens of group B streptococci types Ia, Ib and III: low antibody levels in mothers of neonatally infected infants. Scand $J$ Infect Dis 12:105-110

25. Baker CJ, Kasper DL 1976 Correlation of maternal antibody deficiency with susceptibility to neonatal group B streptococcal infection. N Engl J Med 294:753-756

26. Christensen KK, Christensen P, Duc G, Hitzig WH, Linden V, Muller B, Seger RA 1984 Human IgG antibodies to carbohydrate and protein antigens in mouse protection tests with group B streptococci. Pediatr Res 18:478-482

27. Christensen RD, Rothstein G, Hill HR, Pincus SH 1984 Treatment of experimental group B streptococcal infection with hybridoma antibody. Pediatr Res 18:1093-1096 
28. Shigeoka AO, Pincus SH, Rote NS, Hill HR 1984 Protective efficacy of hybridoma type-specific antibody against experimental infection with groupB Streptococcus. J Infect Dis 149:363-372

29. Van Dijk WC, Verbrugh HA, van der Tol ME, Peters R, Verhoef J 1981 Escherichia coli antibodies in opsonisation and protection against infection. J Med Microbiol 14:381-389

30. Stevens P, Huang SN-Y, Welch WD, Young LS 1978 Restricted complement activation by Escherichia coli with the K-1 capsular serotype: a possible role in pathogenicity. J Immunol 121:2174-2180

31. Stevens P, Young LS 1977 Quantitative granulocyte chemiluminescence in the rapid detection of impaired opsonization of Escherichia coli. Infect Immun 16:796-804

32. Söderström T, Stein K, Brinton CC, Hosea S, Burch C, Hansson HA, Karpas A, Schneerson R, Sutton A, Vann WI, Hanson LA 1983 Serological and functional properties of monoclonal antibodies to Escherichia coli type I pilus and capsular antigens. Prog Allergy 33:259-274

33. Welch WD, Martin WJ, Stevens P, Young LS 1979 Relative opsonic and protective activities of antibodies against $\mathrm{K} 1,0$ and lipid $\mathrm{A}$ antigens of Escherichia coli. Scand J Infect Dis 11:291-301

34. Cross AS, Zollinger W, Mandrell R, Gemski P, Sadoff J 1983 Evaluation of immunotherapeutic approaches for the potential treatment of infections caused by K1-positive Escherichia coli. J Infect Dis 147:68-75

35. Kasper DL, Winkelhake JL, Zollinger WD, Brandt BL, Artenstein MS 1973 Immunochemical similarity between polysaccharide antigens of Escherichia coli 07:K1(L):NM and group B Neisseria meningitidis. J Immunol 1 10:262268
36. Wyle FA, Artenstein MS, Brandt BL, Tramont EC, Kasper DL, Altieri PL, Berman SL, Lowenthal JP 1972 Immunologic response of man to group B meningococcal polysaccharide vaccines. J Infect Dis 126:514-522

37. Bortolussi R 1986 Potential for intravenous gamma-globulin use in neonatal gram-negative infection: an overview. Pediatr Infect Dis 5:S198-200

38. Hill HR, Bathras JM 1986 Protective and opsonic activities of a native, ph 4.25 intravenous immunoglobulin $\mathrm{G}$ preparation against common bacterial pathogens. Rev Infect Dis 8:S396-400

39. Pluschke G, Achtman M 1985 Antibodies to O-antigen of lipopolysaccharide are protective against neonatal infection with Escherichia coli $\mathrm{K} 1$. Infect Immun 49:365-370

40. Givner LB, Edwards MS, Anderson DC, Baker CJ 1985 Immune globulin for intravenous use: enhancement of in vitro opsonophagocytic activity of neonatal serum. J Infect Dis 151:217-220

41. Jacobs RF, Kiel DP, Sanders ML, Steele RW 1985 Phagocytosis of type III group B streptococci by neonatal monocytes: enhancement by fibronectin and gammaglobulin. J Infect Dis 152:695-700

42. Emerson TE, Collins MS 1985 Reversal of depressed reticuloendothelial system clearance of pneumococci by immunoglobulin $G$ treatment in the gramnegative bacteremic rat. Clin Res 33:844A(abstr)

43. Lassiter HA, Christensen RD, Rothstein G 1987 Defective killing of E. coli $\mathrm{K} 1$ by neonatal rat serum and correction of this defect by the addition of human IgG. Clin Res 35:235A(abstr)

44. Hathorn JW, DeFranco AC, Hiemenz JW, Cotton DJ, Schaufele R, Sadoff J, Pizzo PA 1983 Enhanced bacterial killing by "armed neutrophils." Pediatr Res 17:272A(abstr) 